\title{
DETAILED MAPPING IN THE SOUTHERN PART OF THE ILÍMAUSSAQ ALKALINE INTRUSION, SOUTH GREENLAND
}

\author{
Steen Andersen
}

The detailed mapping programme in the southern part of the Ilímaussaq intrusion begun in 1972 by the present author (see Andersen et al., 1973) was continued during the summer. The area investigated is situated around hill $435 \mathrm{~m}$, one kilometre south-east of the bay Tuperssuatsiait, to the south of Tunugdliarfik fjord. Up to the present time, about $2 \mathrm{~km}^{2}$ has been mapped at the scale of $1: 5000$.

The study area contains four main rock types: sodalite-foyaite, naujaite, black arfvedsonite-lujavrite and green aegirine-lujavrite, all of which form distinct units. The greater part of the area consists of naujaite. To the east the naujaite is interwoven with an increasing number of lujavrite sheets and the primary aim of the work was to establish the nature of the so-formed lujavrite-breccia. The sodalitefoyaite overlies the naujaite to the west.

\section{Results}

The main results of the mapping are summarised below.

\section{Black, arfvedsonite-rich lujavrite}

(1) The black arfvedsonite-lujavrite composes a much smaller area than suspected from the published 1:20000 geological map. It is found as a limited number of sheets between blocks of naujaite. In detail the single sheets have an irregular outcrop pattern, but in general they dip $20^{\circ}-40^{\circ}$ to the north-west.

(2) It is suggested that all black lujavrite-sheets in the area mapped are intrusive. This is judged from the structural pattern, from the contact relationship to the naujaite and from drawn-out trains of inclusions.

(3) Throughout the area mapped the lujavrite is greyish black with a brownish tint. Schistosity and lamination are well developed but no lineations have been observed. Macroscopically, the lamination is expressed in the parallel arrangement of arfvedsonite, but this texture is probably controlled by parallelism in the alkali feldspars. In most localities the lujavrites have a spotted appearance due to spherical to elliptical, grey, acmite-rich lumps. The size of the lumps varies from $0.5-5 \mathrm{~cm}$, but there is some indication that the percentage $(\sim 25 \%)$ remains the same irrespective of size. Locally the lujavrites are banded in shades of grey and black, probably due to the varying proportions of nepheline and arfvedsonite. 
Banded and spotted sequences may alternate. The banding is especially well developed near Agpat outside the mapped area.

(4) Within the main lujavrite outcrop two sub-provinces can be outlined:

(a) Naujakasite is a common accessory mineral in the north-western part of the area. In this part lujavrite-pegmatites are absent and the contacts between lujavrite and naujaite are simple.

(b) In contrast, no crystals of naujakasite have been observed in the southeastern part of the area. Here the pegmatites are plentiful and green aegirine-rich varieties of lujavrite are often found along the contacts between black lujavrite and naujaite - the latter being often rich in sodalite.

\section{Green, aegirine-rich lujavrite}

(5) In the easternmost part of the area the black lujavrite grades into the green aegirine-rich variety. The boundary is well defined but transitional over about a metre. A few narrow horizons of an aegirine-rich lujavrite occur within the black lujavrite in the vicinity of the contact.

(6) The strictly parallel lamination in the green and black lujavrite is of considerable interest. If the lujavrites are intrusive in origin, as is proposed, this suggests that the magma of both rock types was injected as a single pulse. The conditions controlling the formation of the Fe-rich minerals are thus either sustained in the fluid phase, or are due to differences in the local milieu during cooling.

\section{Naujaite and sodalite-foyaite}

(7) The naujaite to the east of hill $435 \mathrm{~m}$ is rich in sodalite. This sodalite-rich naujaite may belong essentially to a single horizon which follows the topography.

(8) In order to reveal the stratification pattern of the naujaite, layering elements were studied and measured. These are, in increasing frequency but with decreasing reliability, banding, conformable pegmatites and joints. The first assessment of the results suggests a simple, north-west dipping pattern, but many more measurements are needed before a firm conclusion can be drawn.

(9) The easternmost part of the contact between sodalite-foyaite and the lower naujaite has been mapped cursorily. To the west the surface seems to be a regular plane with a low dip to the north for a distance of about $750 \mathrm{~m}$. Thereafter the dip steepens rapidly to the north resulting in the lowering of the northern contact by $100 \mathrm{~m}$. 


\section{Reference}

Andersen, S., Bailey, J., Karup-Møller, S. et al. 1973: Research projects on the Ilímaussaq alkaline intrusion, South Greenland. Rapp. Grgnlands geol. Unders. 55, 38-40.

Institut for Petrologi, University of Copenhagen,

Øster Voldgade 10,

1350 Copenhagen $K$.

\section{HYDROGEOCHEMICAL INVESTIGATIONS ON RIVER WATER IN WEST, SOUTH AND EAST GREENLAND}

\section{Gert Asmund}

Hydrogeochemical investigations have been concerned with the analysis of heavy metals dissolved in stream and river water. The concentrations of metals like $\mathrm{Cu}, \mathrm{Pb}, \mathrm{Ni}, \mathrm{Cr}$, and $\mathrm{Cd}$ are however usually below the level of detection by commonly used water analysis methods. For this reason, and to overcome some of the problems connected with the transportation of water from Greenland to Copenhagen, i.e. contamination of the samples by the container or absorption of metals on the container surface, a new method of analysis was developed two years ago at the Danish Atomic Energy Commission's Research Establishment, Risø.

\section{The method}

Small nylon bags containing heavy metal selective ion exchangers, $1 \mathrm{~g}$ weight, are placed in the streams for a period of not less than 14 days. This is sufficient time for the ion exchanger and the water to be brought into equilibrium. The bags are then collected and analysed for the desired elements. The concentration factor is in the range of 100000 , which means, that water containing $0.1 \mathrm{ppb}$ dissolved metal yields an ion exchanger with $10 \mathrm{ppm}$, which is easy to analyse by optical spectrography. The main theoretical problem is to determine the concentration factor and to achieve reasonable reproducibility.

\section{Field work}

In the summer of 1972 the method was tested for the first time at various places in Greenland, when Survey personnel working essentially on other projects undertook to place ion exchange samplers in rivers and lakes (see e.g. Andersen et al., 1973). In the summer of 1973 the work was continued. The author visited the Narssaq area in South Greenland where a large programme was embarked 